\title{
Assessment of Trace Metal Contents of Indigenous and Improved Pastures and Their Implications for Livestock in Terms of Seasonal Variations
}

\author{
MIAN JAHANZAIB RASHEED ${ }^{1}$, KAFEEL AHMAD ${ }^{1}$, ZAFAR IQBAL KHAN ${ }^{1 *}$, \\ SHAHZADI MAHPARA ${ }^{2}$, TASNEEM AHMAD ${ }^{3}$, YONGJUN YANG ${ }^{4}$, KINZA WAJID ${ }^{1}$, \\ MUHAMMAD NADEEM ${ }^{5}$, HUMAYUN BASHIR ${ }^{1}$, ASMA ASHFAQ ${ }^{1}$, MUDASRA MUNIR ${ }^{1}$, \\ IFRA SALEEM MALIK ${ }^{1}$, IJAZ RASOOL NOORKA ${ }^{6}$, MADIHA KIRAN ${ }^{7}$, \\ MUHAMMAD FIAZ QAMAR ${ }^{7}$, ILKER UGULU ${ }^{8}$ \\ ${ }^{1}$ Department of Botany, University of Sargodha, Sargodha, Pakistan \\ ${ }^{2}$ Department of Plant Breeding and Genetics, Ghazi University, Dera Ghazi Khan, Pakistan \\ ${ }^{3}$ Pakki Thatti R \& D Farm, Toba Tek Singh, Pakistan \\ ${ }^{4}$ School of Environment Science and Spatial Informatics, China University of Mining and Technology, Xuzhou, China \\ ${ }^{5}$ Institute of Food Science and Nutrition, University of Sargodha, Sargodha, Pakistan \\ ${ }^{6}$ Plant Breeding and Genetics, Agriculture College, University of Sargodha, Sargodha, Pakistan \\ ${ }^{7}$ Department of Pathobiology, University of Veterinary and Animal Sciences, Lahore sub-campus, Jhang, Pakistan \\ ${ }^{8}$ Faculty of Education, Usak University, Usak, Turkey
}

\begin{abstract}
The research was aimed to determine seasonal effects on trace metals levels in soil, forages and blood plasma of animals. The mean cadmium, chromium and copper values in soil samples in different sampling seasons were ranged from 6.97 to $4.10,0.060$ to 0.72 and 3.54 to $4.08 \mathrm{mg} / \mathrm{kg}$, respectively, while, in forage samples were between 0.671-0.697, 1.57-2.22 and 6.75-7.06 $\mathrm{mg} / \mathrm{kg}$, respectively. Higher $\mathrm{Cd}, \mathrm{Cr}$ and $\mathrm{Cu}$ concentrations were observed in blood plasma of young buffaloes during summer season, in dry buffaloes during spring season and in young buffaloes during autumn season, while lower $\mathrm{Cd}, \mathrm{Cr}$ and $\mathrm{Cu}$ contents were noticed in blood plasma of lactating buffaloes in summer season. The highest bio-concentration factor value from soil to forage was determined for $\mathrm{Cr}$ while from forage to blood plasma of buffaloes was detected for $\mathrm{Cd}$. The $\mathrm{Cd}, \mathrm{Cr}$ and $\mathrm{Cu}$ correlation of soil with blood plasma were positive for all samples.
\end{abstract}

Keywords: buffalo, forage, soil, trace metal

\section{Introduction}

In the balanced diet of organisms minerals play vital role throughout their life. If mineral concentration is improper, the activities of animals in livestock minimized. For popper growth of livestock animals various macro and micro minerals are essential [1]. The macro minerals such as phosphorus, calcium and magnesium play an important role for proper lactation, growth and reproduction of ruminants. On the other hand, the micro-minerals like trace metals such as cadmium, chromium and copper are very important to improve human and animal health [2].

In animal's feed the minerals requirement cannot be denied because they have crucial role in the normal physiological functions of animal body, their growth and reproduction. Therefore, in the mineral requirements of animals there is high level of uncertainty depending upon level of production, age, breed, dietary antagonist, animal adaptation and interrelationship with other nutrients [3]. Soil properties and mineral profile affect the mineral deficiencies in grazing livestock [4].

Mineral imbalances in soil and forages have long been held responsible for low production and reproductive problems among grazing ruminants in the world. In spite of very much importance of minerals in ruminant nutrition, very little information is available on the mineral status of livestock in Pakistan.

*email: zafar.hed@gmail.com 
There are number of methods to evaluate the mineral status of livestock, but animal fluid and tissue mineral concentration are better indicators of the availability of most minerals. Grazing animals frequently obtain their mineral nutrition by consuming water, soil, leaves, tree branches etc, rather than entirely from forages. So the livestock fluid and tissue mineral concentrations are more accurately related to animal environmental conditions, in meeting the mineral requirements for their production [5].

Mineral deficiencies, imbalances and toxicities have been reported to inhibit ruminant production systems [6]. So, there is need to explore the forage mineral status which fulfil the nutritional requirements of buffaloes. It establishes baseline data that is essential for formulating ways of supplementing minerals to improve buffalo production. This work will provide baseline information to farmers and animal nutritionists on the seasonality of trace metals in soil, plant material and blood plasma of buffaloes, which is essential for formulating supplements to improve productivity. It will provide a description of trace metal levels in buffaloes for diagnosing the deficiencies and toxicities to institute corrective or preventive measures. In this direction, the main objective of the present study was to determine trace metal contents and particularly to find out the effect of season on the levels of trace metals in forages and blood plasma of animals.

\section{Materials and methods}

\subsection{Study site}

Khushab is that district of Punjab which was elicited for demonstrative study (Figure 1). Khushab is populated with 102,793 inhabitants and is roughly160 $\mathrm{km}$ from Lahore.

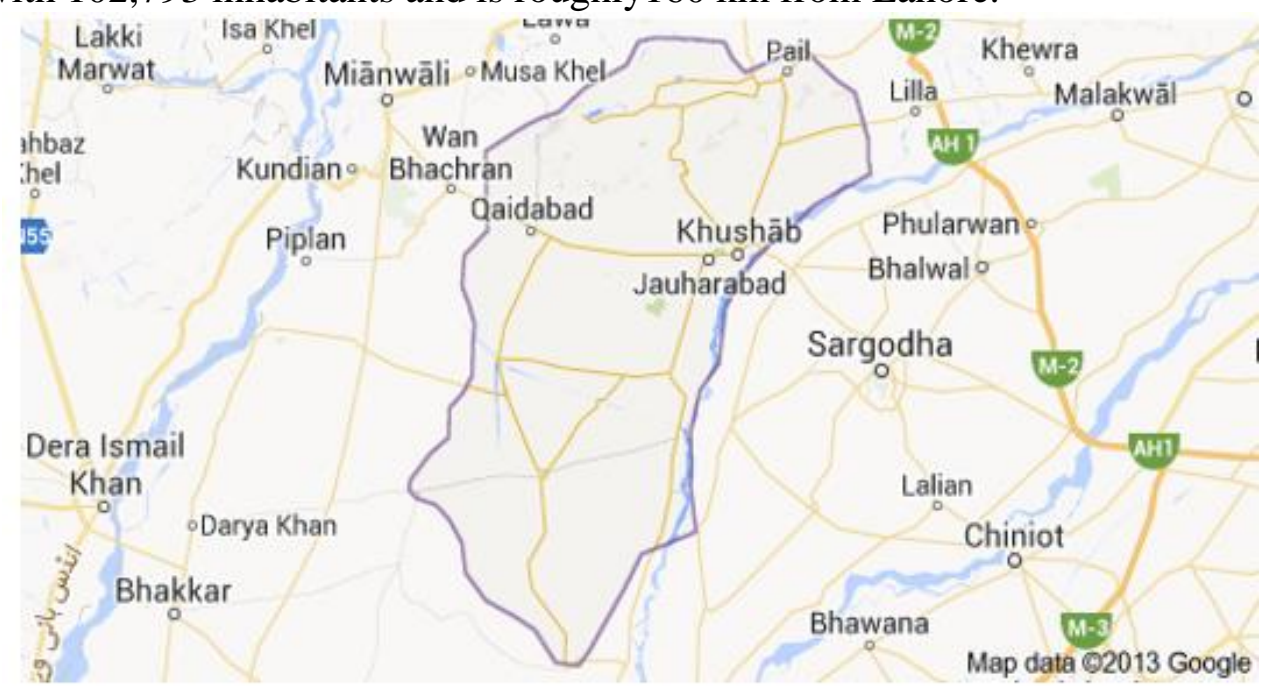

Figure 1. Geographical location of study area

\subsection{Samples collection and preparation}

\subsubsection{Soil}

Ten feeding sites were selected randomly from each agro-ecological zone i.e. from where the fodder samples under study were collected. Soil samples were taken from half to $1 \mathrm{ft}$ depth four times in a year of summer, winter, autumn and spring seasons. Soil samples after air dried, were placed in hot air oven till constant weight and ground, stored in labelled bags for further processing. After that, samples were digested [7]. Soil sample (1g) was digested with $\mathrm{H}_{2} \mathrm{SO}_{4}(4 \mathrm{~mL})$ and $\mathrm{H}_{2} \mathrm{O}_{2}(8 \mathrm{~mL})$ in digestion chamber. After digestion, sample diluted, filtered and saved in labelled plastic bottles.

\subsubsection{Forage}

The sterilized apparatus can be used for sampling from similar site while these forages that were grazed by buffaloes. Composite fodder samples were collected that were being served to the buffaloes at the time of blood sample collection (Table 1). Traditionally mixed fodders (at least two fodder 
species) are served to the buffaloes. The collected forage samples were digested with $2 \mathrm{~mL}$ of sulphuric acid solution plus $4 \mathrm{~mL}$ of hydrogen per oxide solution and put in digestion chamber. After digestion, sample diluted, filtered and saved in labelled plastic bottles.

Table 1 . The collected forage samples during different seasons

\begin{tabular}{|c|c|c|c|}
\hline Sampling & Season & Common Name & Scientific name \\
\hline $1^{\text {th }}$ & Summer & $\begin{array}{c}\text { Maize } \\
\text { Jowar }\end{array}$ & $\begin{array}{c}\text { Zea mays } \\
\text { Sorghum bicolour }\end{array}$ \\
\hline $2^{\text {nd }}$ & Autumn & $\begin{array}{c}\text { Bajra } \\
\text { Guar }\end{array}$ & $\begin{array}{c}\text { Pennisetum glaucum } \\
\text { Cyamopsis tetragonoloba }\end{array}$ \\
\hline $3^{\text {rad }}$ & Winter & $\begin{array}{c}\text { Barseeem } \\
\text { Luceme }\end{array}$ & $\begin{array}{c}\text { Trifolium alexandrimum } \\
\text { Medicago sativa }\end{array}$ \\
\hline $4^{\text {th }}$ & Spring & $\begin{array}{c}\text { Sarsoon } \\
\text { Barseem }\end{array}$ & $\begin{array}{c}\text { Brassica campestris } \\
\text { Trifolium alexandrimum }\end{array}$ \\
\hline
\end{tabular}

\subsubsection{Blood plasma}

The Nili Ravi buffaloes maintained under the existing field conditions comprised of the study animals. In current research thirty buffaloes (Nili-Ravi) were selected and divided into three categories lactating, non-lactating and young. Four samplings were done in different seasons (summer, autumn, winter and spring) and 10 blood plasma samples were collected from each category of Nili-Ravi buffaloes during each sampling period. The sterilized needle was used for blood sampling from the jugular vein of standing position buffalo and these samples were placed immediately in the heparin of sodium citrate voiles to blocked the clot forming. Centrifugation was done for serum separation from blood plasma. Then in last serum was poured in labelled small voiles and stored at $-20^{\circ} \mathrm{C}$. For digestion, same procedure was followed as in forages digestion.

\subsection{Quality control}

Being repeated study of samples assured the accuracy and precision of analysis versus nutritional institute of standard and technology, (SRM 1570) is the standard reference material for heavy metals. Within $\pm 2 \%$ resulted readings were observed of the documented worth. For the assessment of contamination and reliability of data, quality control measures had been taken. To calibrate the instrument, bank and be adrift were observed after five findings. For opposite determinations and for the precision of analysis and variations that could be considered right if it will be less than $10 \%$, after the determination of coefficient of replicate analysis.

\subsection{Preparing of standard}

For receiving accurate results, instruments must be calibrated with standard before the using for analysis. Standard preparation is also necessary for the washing of glassware that will be used in analysis. Take sample in a beaker and weighing on an analytical balance, it has dissolved in little amount of water or in another solvent and placed on a hot plate to make speedy dissolution. Before making further processes, we must be sure that the sample had fully dissolved. A measured amount of solution was transferred in a volumetric flask. Thoroughly wash the glassware like a beaker, funnel etc. and stirring the flask with deionized water so that to ensure, that dissolved samples have been entirely shifted to $2^{\text {nd }}$ flask. Thoroughly rinse the beaker with distilled water and up to mark little below the $100 \mathrm{~mL}$ line. Then deionized water was added carefully with dropper until the meniscus touched up to $100 \mathrm{~mL}$ mark. For good mixing, hold the stopper tightly and agitate the flask again and again. Make sure that uniform solution filled in the flask. Must be the same concentration of the solution and it can ensure that its bottom is exactly at $100 \mathrm{~mL}$ if needed. 


\subsection{Instrumentation}

As a result of wet digestion, atomic absorption spectrophotometer was used to analyzed the forage and blood plasma samples (AA 5000) for the assessment of mineral concentration in all collected samples. Trace metals like zinc, iron and lead were evaluated in exhibition analytic process. The detective limits of AAS for the above metals are given in (Table 2).

Table 2. Detection limits of atomic absorption spectrophotometer

\begin{tabular}{|l|c|}
\hline Elements & Detection limits \\
\hline Cadmium & 0.8 (Flame AA) \\
\hline Chromium & 3 (Flame AA) \\
\hline Coppe & 15 (Flame AA) \\
\hline
\end{tabular}

\subsection{Physico-chemical analysis of water and soil samples}

The $p \mathrm{H}$ of all soil samples was calculated via usage of 1:2(w/v) soil and water ratio. The $p \mathrm{H}$ of soil was measured via $\mathrm{pH}$ meter. Electrical conductivity was determined via adding 5 grams soil in $10 \mathrm{~mL}$ of distilled water to make a suspension (1:2w/vas in ) [8](De Vos et al. 2007).

\subsection{Statistical analysis}

Data obtained from each parameter was analysed statistically using the SPSS software, descriptive analysis, ANOVA, transfer factor and correlation was worked out [9]

\subsection{Correlation}

Pearson's correlation coefficient was used to find out the relationship of diverse heavy metals in soil and plants.

\subsection{Bio concentration factor}

It is applied to examine the proportion of metal contents in plants to that in corresponding soil. It was used to evaluate the uptake of metals from soil and their bioaccumulation in vegetable using the following formula:

$$
\text { BCF soil-forage }=\text { Metal contents in forage/Metal content in soil }
$$

And similarly, bioconcentration factor $(\mathrm{BCF})$ from forage to blood plasma:

$$
\text { BCF forage-plasma }=\text { Metal contents in plasma/Metalcontents in forage }
$$

\section{Results and discussions}

\subsection{Physiochemical characterization of water}

The $p \mathrm{H}$ value of water samples was the highest at winter sampling season and the lowest $\mathrm{pH}$ value was found summer sampling season (Table 3). Electrical conductivity is another important indicator to check the ionic content of water. In present study, the range of EC in all treatments was ranged from 280 to $321 \mathrm{dS} / \mathrm{m}$ Present results showed higher EC values than the values determined by Pandey and Singh [10]. They observed EC value $7.8 \mathrm{dS} / \mathrm{m}$ in their research. According to USDA, the EC value of irrigation water quality and the EC value of standard limit for irrigation should be lower than 0.7 and 3 $\mathrm{dS} / \mathrm{m}$, respectively. It was revealed that present value for EC was not in permissible limits.

The value of $\mathrm{Ca}^{2+}$ and $\mathrm{Mg}^{2+}$ varied 92-112 and 32-38 mg/L respectively and Chloride ranged from 47 to $55 \mathrm{mg} / \mathrm{L}$ with mean concentration of $47,49,50$, and $55 \mathrm{mg} / \mathrm{L}$ for summer, spring, autumn and winter seasons, respectively. The range of total dissolved solid was 130 to $135 \mathrm{mg} / \mathrm{L}$ with the mean 
concentration of $6.2,38.2,540$, and $894 \mathrm{mg} / \mathrm{L}$ respectively. Total hardness and alkalinity varied 95 100 and $100-121 \mathrm{mg} / \mathrm{L}$ respectively (Table 3 ).

Table 3.Physiochemical characterization of water at different sampling seasons

\begin{tabular}{|c|c|c|c|c|c|c|}
\hline \multirow{2}{*}{ Parameters } & \multirow{2}{*}{$\begin{array}{c}\text { WHO } \\
\text { desirable } \\
\text { limit }\end{array}$} & \multirow{2}{*}{$\begin{array}{c}\text { WHO } \\
\text { Max. permissible } \\
\text { limit }\end{array}$} & \multicolumn{4}{|c|}{ Sampling season } \\
\hline & & & Summer & Autumn & Winter & Spring \\
\hline $\mathrm{pH}$ & $7-8.5$ & $6.5-9.2$ & 7.8 & 8 & 8.2 & 7.9 \\
\hline Calcium (mg/L) & 75 & 200 & 92 & 100 & 112 & 98 \\
\hline Magnesium (mg/L) & 50 & 150 & 32 & 36 & 34 & 38 \\
\hline Chloride (mg/L) & 200 & 600 & 47 & 50 & 55 & 49 \\
\hline Electrical conductivity (us/cm) & - & - & 280 & 300 & 321 & 289 \\
\hline Total dissolved solid (mg/L) & 500 & 1000 & 130 & 130 & 135 & 135 \\
\hline Total hardness $\left(\mathrm{CaCo}_{3}\right)(\mathrm{mg} / \mathrm{L})$ & 100 & 500 & 100 & 98 & 95 & 97 \\
\hline Total alkalinity as $\mathrm{CaCo}_{3}(\mathrm{mg} / \mathrm{L})$ & - & 500 & 112 & 100 & 112 & 121 \\
\hline
\end{tabular}

Conductivity is directly related with various water properties. Alkalinity, $\mathrm{pH}$ and hardness affect the toxicity of many substances in the water [11].

\subsection{Physiochemical characterization of soil}

The $p \mathrm{H}$ value of soil samples was highest at summer sampling season and the lowest $\mathrm{pH}$ value was found at spring sampling season (Table 4). Range of electrical conductivity among all sites was observed between $0.22-0.29 \mathrm{~ms} / \mathrm{cm}$. No risk of salinity and sodicity was found in the soil at three sites as EC values were lower than the threshold values of EC $(4 \mathrm{dS} / \mathrm{m})$. Textural class of the soil samples for four seasons was loamy with a $p \mathrm{H}$ range of 8.1-8.9 (Table 4).

Table 4. Physiochemical characterization of soil at different sampling seasons

\begin{tabular}{|c|c|c|c|c|c|}
\hline \multirow{2}{*}{ Parameter } & \multirow{2}{*}{ Unit } & \multicolumn{4}{|c|}{ Sampling season } \\
\cline { 3 - 6 } & & Summer & Autumn & Winter & Spring \\
\hline Ph & & 8.9 & 8.5 & 8.7 & 8.1 \\
\hline Electrical conductivity & $\mathrm{dS} / \mathrm{m}$ & 0.24 & 0.25 & 0.22 & 0.29 \\
\hline Organic matter & $(\%)$ & 0.68 & 0.67 & 0.7 & 0.71 \\
\hline Phosphorus & $\mathrm{Ppm}$ & 8.5 & 9 & 9.5 & 9.2 \\
\hline Potassium & Ppm & 132 & 135 & 437 & 130 \\
\hline Saturation & $\%$ & 44 & 44 & 44 & 44 \\
\hline Texture & & loamy & loamy & loamy & loamy \\
\hline
\end{tabular}

According to laboratory test, the soil samples are deficient with organic matter percentage contents and need fertilizers to enhance its fertility. Soil $p \mathrm{H}$ is the only feature of soil that clarifies a whole 
image of the medium for plant growth comprising soil mineralogy, method for nutrient supply, salinity/sodicity position and soil exposure to air, destiny of nutrients added and final weather situations of the area. The numerical values are each time within limit of 8.0-8.4 in normal soil where as in Pakistan $p \mathrm{H}$ of sodic soils might reach 10.00. Therefore, a reduction in soil $p \mathrm{H}$ because of some land management strategy is every time considerable and effects in eventual alteration of soil medium into positive one and remaining translation into improved yields. Outcomes on $p \mathrm{H}$ were alike by manure alone or its mixture by fertilizer at similar level of application. Numerical values were minute less next to wheat in the similar treatments representing constant progressive effect of manure on such soil limitation. Smiciklas-Wright et al. [11], Pattanayak et al. [12], Yadav and Khirwar [13] also observed a decrease in soil $\mathrm{pH}$ after the use of organic materials.

\subsection{Cadmium contents of samples}

\subsubsection{Soil}

The mean Cd levels in soil samples during various sampling seasons are listed in Table 5 and Table 6. According to ANOVA, the mean $\mathrm{Cd}$ concentrations in soil samples affected non-significantly ( $p>0.001)$ by sampling seasons. The mean Cd contents in different sampling seasons were ranged from 6.97 to $4.10 \mathrm{mg} / \mathrm{kg}$. Higher mean Cd contents were found in soil samples collected during autumn sampling season and lower $\mathrm{Cd}$ concentrations were observed during summer sampling season (Figure 2). The mean values of Cd contents in the different sampling seasons were $4.10 \mathrm{mg} / \mathrm{kg}$ (summer), 6.97 $\mathrm{mg} / \mathrm{kg}$ (autumn), $4.73 \mathrm{mg} / \mathrm{kg}$ (winter) and $5.17 \mathrm{mg} / \mathrm{kg}$ (spring). The order of the obtained Cd mean values in all soil samples were determined as autumn>spring > winter>summer. The mean $\mathrm{Cd}$ contents in soil samples exhibited inconsistent pattern of variation along the sampling seasons.

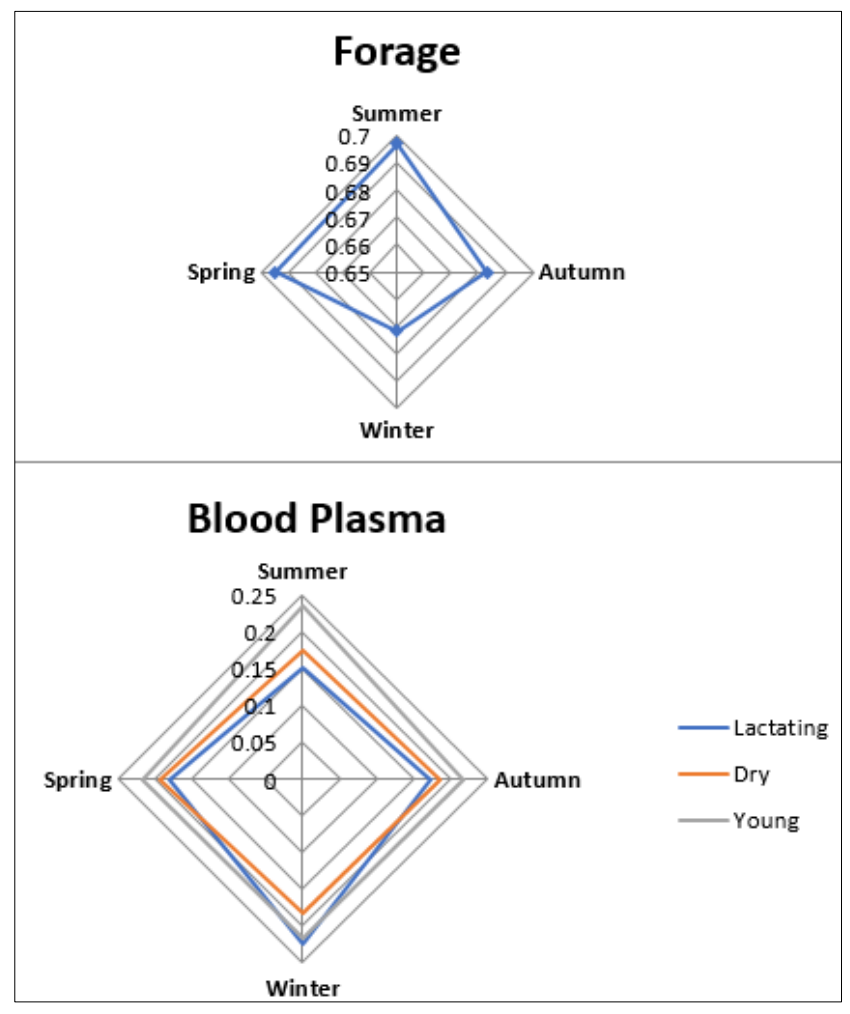

Figure 2. Fluctuations in cadmium values in soil, forage and blood plasma during different seasons

Ruminant health is influenced by minerals uptake from feed, but minerals in feed depends on availability from soil [14]. The determined $\mathrm{Cd}$ values in this study are minimum than the Cd content (3 $\mathrm{mg} / \mathrm{kg}$ ) as noted by McDowell [15]. In contrast to this, recent results were in accordance with $\mathrm{Cd}$ present in soil concentration as specified before [16]. Thus, the recent results were lower than the concentrations of $\mathrm{Cd}$ in soil as described before [17-19]. The soil fertility has to be maintained by 
adding organic matter into soil. Nutrients are made available to the plants when certain factors are fulfilled [20]. The presence of major minerals and trace minerals in the fodders mainly depends on their level in the soil on which the fodder is grown [21].

\subsubsection{Forage}

The average Cd contents in forage during various sampling seasons are summarized in Table 5 and Table 6. According to the analysis of variance, the mean $\mathrm{Cd}$ concentrations in forage samples affected non-significantly $(p>0.05)$ by sampling seasons. The mean $\mathrm{Cd}$ contents in different sampling seasons were ranged from 0.671 to $0.697 \mathrm{mg} / \mathrm{kg}$. Higher mean $\mathrm{Cd}$ contents were found in forage samples collected during summer sampling season and lower $\mathrm{Cd}$ concentrations were observed during winter sampling season (Figure 2). The mean values of $\mathrm{Cd}$ contents in the different sampling seasons were $0.697 \mathrm{mg} / \mathrm{kg}$ (summer), $0.682 \mathrm{mg} / \mathrm{kg}$ (autumn), $0.671 \mathrm{mg} / \mathrm{kg}$ (winter) and $0.694 \mathrm{mg} / \mathrm{kg}$ (spring). The order of the obtained $\mathrm{Cd}$ mean values in all forage samples were determined as summer>spring> autumn>winter. The mean $\mathrm{Cd}$ contents in forage samples exhibited inconsistent pattern of variation along sampling seasons.

Cadmium concentration found in the present investigation was higher than values $(0.03 \mathrm{mg} / \mathrm{kg})$ established by Kloke [22]. The maximum Cd content in plants was recommended about $3.0 \mathrm{mg} / \mathrm{kg}$ by Cicek et al. [23]. In this study Cd contents were minimum than the recommended toxic level by Aksoy [24] and has no potential threat for livestock. The Cd level investigated at present was also lower than the earlier as accounted by Gowda et al. [25]. Various factors determine the bioavailability of minerals in plant systems [26].

\subsubsection{Blood plasma}

The average Cd contents in blood plasma samples of buffaloes during various sampling seasons are summarized in Table 5 and Table 6 . While the $\mathrm{Cd}$ concentration in blood plasma significantly $(p<0.001)$ affected by sampling seasons in lactating buffaloes, it was non-significantly $(p>0.05)$ affected by the sampling seasons in dry and young buffaloes. The mean $\mathrm{Cd}$ values in blood plasma of lactating buffaloes were $0.151 \mathrm{mg} / \mathrm{L}$ (summer), $0.174 \mathrm{mg} / \mathrm{L}$ (autumn), $0.224 \mathrm{mg} / \mathrm{L}$ (winter), and 0.181 $\mathrm{mg} / \mathrm{L}$ (spring). The mean $\mathrm{Cd}$ concentration in blood plasma of dry buffaloes were $0.175 \mathrm{mg} / \mathrm{L}$ (summer), $0.187 \mathrm{mg} / \mathrm{L}$ (autumn), $0.182 \mathrm{mg} / \mathrm{L}$ (winter) and $0.195 \mathrm{mg} / \mathrm{L}$ (spring). The average Cd contents in blood plasma of young buffaloes were $0.236 \mathrm{mg} / \mathrm{L}$ (summer), $0.217 \mathrm{mg} / \mathrm{L}$ (autumn), 0.217 $\mathrm{mg} / \mathrm{L}$ (winter), and $0.218 \mathrm{mg} / \mathrm{L}$ (spring). Higher mean Cd concentrations were observed in the blood plasma of young buffaloes during summer season and lower mean $\mathrm{Cd}$ contents were noticed in the blood plasma of lactating buffaloes in summer sampling season (Figure 2). The detected orders of the $\mathrm{Cd}$ contents were in lactating buffaloes as winter $>$ spring>autumn $>$ summer, in dry buffaloes as spring $>$ autumn $>$ winter $>$ summer and in young buffaloes as summer $>$ spring $>$ autumn $>$ winter.

Table 5. Analysis of variance for cadmium concentrations in soil, forage and blood plasma influenced by different seasons

\begin{tabular}{|c|c|c|c|c|c|c|}
\hline \multirow{3}{*}{$\begin{array}{l}\text { Source of } \\
\text { variation }\end{array}$} & \multirow{3}{*}{$\begin{array}{l}\text { Degrees } \\
\text { of } \\
\text { freedom }\end{array}$} & \multicolumn{5}{|c|}{ Mean Squares } \\
\hline & & \multirow[b]{2}{*}{ Soil } & \multirow[b]{2}{*}{ Forage } & \multicolumn{3}{|c|}{ Blood plasma } \\
\hline & & & & $\begin{array}{l}\text { Lactating } \\
\text { buffaloes }\end{array}$ & Dry buffaloes & $\begin{array}{c}\text { Young } \\
\text { buffaloes }\end{array}$ \\
\hline $\begin{array}{l}\text { Sampling } \\
\text { Season }\end{array}$ & 3 & $45.391^{\mathrm{ns}}$ & $0.004^{\mathrm{ns}}$ & $0.029 * * *$ & $0.002^{\mathrm{ns}}$ & $0.002^{\mathrm{ns}}$ \\
\hline Error & 36 & 0.483 & 0.008 & $\begin{array}{l}0.0 \\
01\end{array}$ & 0.001 & 0.001 \\
\hline
\end{tabular}


Table 6. Descriptive analysis for cadmium concentrations in soil, forage and blood plasma influenced by different seasons

\begin{tabular}{|c|c|c|c|c|c|}
\hline \multirow{2}{*}{ Parameter } & \multirow{2}{*}{ Soil } & \multirow{2}{*}{ Forage } & \multicolumn{3}{|c|}{ Blood plasma } \\
\cline { 4 - 6 } & & & $\begin{array}{c}\text { Lactating } \\
\text { buffaloes }\end{array}$ & Dry buffaloes & $\begin{array}{c}\text { Young } \\
\text { buffaloes }\end{array}$ \\
\hline Mean & 5.242 & 0.687 & 0.184 & 0.185 & 0.223 \\
\hline Std. Error \pm & 0.132 & 0.015 & 0.005 & 0.004 & 0.004 \\
\hline Median & 4.823 & 0.670 & 0.179 & 0.178 & 0.221 \\
\hline Mode & $3.975^{\mathrm{a}}$ & 0.765 & $0.107^{\mathrm{a}}$ & 0.137 & 0.241 \\
\hline Std. Deviation & 1.440 & 0.161 & 0.051 & 0.047 & 0.0412 \\
\hline Minimum & 2.983 & 0.356 & 0.103 & 0.101 & 0.101 \\
\hline Maximum & 8.455 & 0.994 & 0.326 & 0.326 & 0.320 \\
\hline
\end{tabular}

a. Multiple modes exist. The smallest value is shown

Ruminant health directly relates with feed quality [27,28,29] The values found in the present investigation are higher than the $\mathrm{Cd}$ contents $(0.1 \mathrm{mg} / \mathrm{L})$ reported by WHO [30]. One of the environmental sources of trace minerals is weathering of soil which becomes the serious pollution agents [31,32].

In animal diets, the maximum tolerated concentration of $\mathrm{Cd}$ is $0.5 \mathrm{mg} / \mathrm{kg}[33,34]$. If diet contain 5 to $30 \mathrm{mg} \mathrm{Cd}$ dose it is thought to be toxic for buffaloes. Many observations illustrated that $\mathrm{Cd}$ poisoning mechanism is based on ingested dose, mineral flow in organism, during of exposure to mineral element metal chemical form, age and species of animal [35,36]. Cd damages adhesion between DNA, energy metabolism and cells [37-40]. It also rigorously interferes on cell metabolism as a result death of mice cell occurs [41,42]. Based on type of cell this mineral element induces two types of cell death: necrosis and apoptosis [43].

\subsection{Chromium contents of samples}

\subsubsection{Soil}

The mean $\mathrm{Cr}$ contents in soil samples during various sampling seasons are showed in Table 7 and Table 8. According to ANOVA, the mean $\mathrm{Cr}$ contents in soil samples affected significantly $(p<0.01)$ by sampling seasons. The mean $\mathrm{Cr}$ concentrations in different sampling seasons varied from 0.060 to $0.72 \mathrm{mg} / \mathrm{kg}$. Higher mean $\mathrm{Cr}$ values were observed in soil samples collected during summer sampling season and lower $\mathrm{Cr}$ concentrations were found during winter sampling season (Figure 3). The mean values of Cr contents in various sampling seasons were $0.060 \mathrm{mg} / \mathrm{kg}$ (summer), $0.062 \mathrm{mg} / \mathrm{kg}$ (autumn), $0.072 \mathrm{mg} / \mathrm{kg}$ (winter) and $0.061 \mathrm{mg} / \mathrm{kg}$ (spring). The order of the observed mean Cr contents in all soil samples were determined as summer>spring>autumn>winter. The mean $\mathrm{Cr}$ contents in soil samples showed inconsistent pattern of variation during various sampling seasons.

Table 7. Analysis of variance for chromium concentrations in soil, forage and blood plasma influenced by different seasons

\begin{tabular}{|c|c|c|c|c|c|c|}
\hline \multirow{3}{*}{$\begin{array}{l}\text { Source of } \\
\text { variation }\end{array}$} & \multirow{3}{*}{$\begin{array}{l}\text { Degrees } \\
\text { of freedom }\end{array}$} & \multicolumn{5}{|c|}{ Mean squares } \\
\hline & & \multirow[b]{2}{*}{ Soil } & \multirow[b]{2}{*}{ Forage } & \multicolumn{3}{|c|}{ Blood plasma } \\
\hline & & & & $\begin{array}{l}\text { Lactating } \\
\text { buffaloes }\end{array}$ & Dry buffaloes & Young buffaloes \\
\hline $\begin{array}{l}\text { Sampling } \\
\text { Season }\end{array}$ & 3 & $0.001^{* *}$ & $2.923 \mathrm{~ms}$ & $0.297^{888}$ & $0.078^{\mathrm{ns}}$ & 0.193 us \\
\hline Error & 36 & 0.000 & 1.013 & 0.014 & 0.012 & 0.025 \\
\hline
\end{tabular}


Table 8. Descriptive analysis for chromium concentrations in soil, forage and blood plasma influenced by different seasons

\begin{tabular}{|c|c|c|c|c|c|}
\hline \multirow{2}{*}{ Parameter } & \multirow{2}{*}{ Soil } & \multirow{2}{*}{ Forage } & \multicolumn{3}{|c|}{ Blood plasma } \\
\cline { 4 - 6 } & & & $\begin{array}{c}\text { Lactating } \\
\text { buffaloes }\end{array}$ & Dry buffaloes & $\begin{array}{c}\text { Young } \\
\text { buffaloes }\end{array}$ \\
\hline Mean & 0.064 & 1.74734 & 0.597 & 0.624 & 0.567 \\
\hline Std. Error \pm & 0.0012 & 0.154208 & 0.024 & 0.017 & 0.018 \\
\hline Median & 0.063 & 1.58150 & 0.628 & 0.634 & 0.539 \\
\hline Mode & 0.057 & $1.435^{\mathrm{a}}$ & $0.423^{\mathrm{a}}$ & 0.682 & $0.544^{\mathbf{2}}$ \\
\hline Std. Deviation & 0.0132 & 1.689261 & 0.222 & 0.176 & 0.192 \\
\hline Minimum & 0.042 & 1.095 & 0.109 & 0.245 & 0.208 \\
\hline Maximum & 0.097 & 19.880 & 0.998 & 0.998 & 0.976 \\
\hline
\end{tabular}

a. Multiple modes exist. The smallest value is shown

Chromium values in soil were more than Cr content $(0.02 \mathrm{mg} / \mathrm{kg})$ determined by Anderson et al. [44]. Variuos factors determine the fate of minerals in soil [45]. In the present study, the Cr content in soil is higher than the values reported by Baron et al. [46] and lesser than the values recognized by [26]. who measured that in soils critical value of $\mathrm{Cr}$ is $75 \mathrm{mg} / \mathrm{kg}$. Industrial effluents and discharge of electric utilities influence $\mathrm{Cr}$ contents in soils [47]. The potential sources of $\mathrm{Cr}$ exposure are slag and solid waste produced during processes of chromate processing [48,49]. Moreover, $\mathrm{Cr}$ is found abundantly in soil rather in crops [50]. The mean $\mathrm{Cr}$ contebt was lower in recent study when compared to $\mathrm{Cr}$ content $(44.72 \mathrm{mg} / \mathrm{kg})$ as explained by $\mathrm{Wu}$ et al. [51] and reported by Ghanem et al. [52], but higher as reported by Rui et al. [53]. These results appeared to be in line with the findings from Kelly [54].

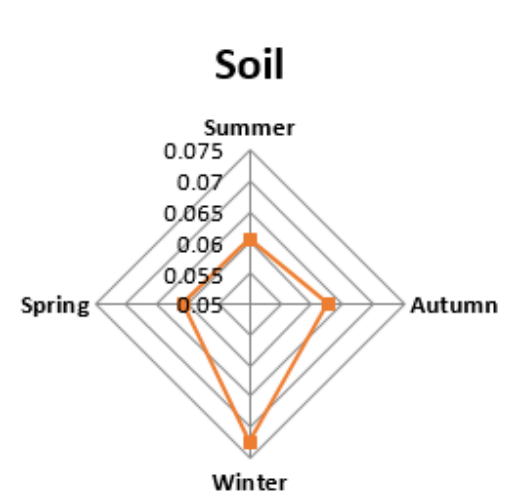

Blood Plasma

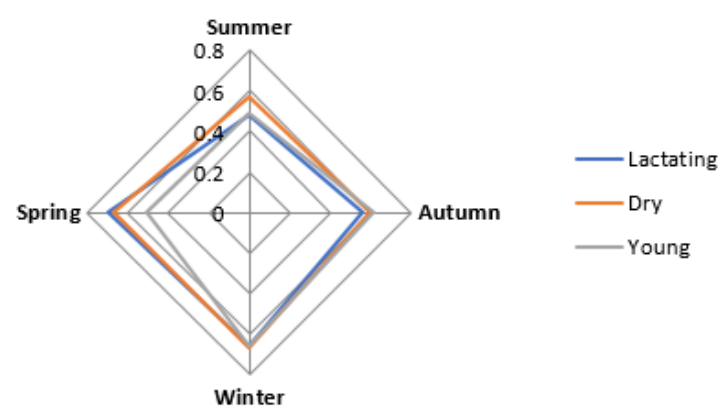

Forage

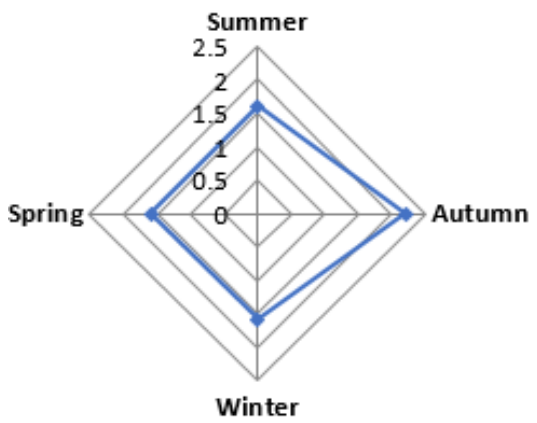

Figure 3. Fluctuations in chromium values in soil, forage and blood plasma during different seasons

\subsubsection{Forage}

The mean $\mathrm{Cr}$ contents in forage during various sampling seasons are presented in Table 7 and Table 8. According to the analysis of variance, the $\mathrm{Cr}$ mean contents in forage samples affected nonsignificantly $(p>0.05)$ by sampling seasons. The mean $\mathrm{Cr}$ concentrations in different sampling seasons varied from 1.57 to $2.22 \mathrm{mg} / \mathrm{kg}$. Higher mean $\mathrm{Cr}$ values were observed in forage samples collected 
during summer sampling season and lower $\mathrm{Cr}$ concentrations were found during winter sampling season (Figure 3). The mean values of $\mathrm{Cr}$ contents in the various sampling seasons were $1.60 \mathrm{mg} / \mathrm{kg}$ (summer), $2.22 \mathrm{mg} / \mathrm{kg}$ (autumn), $1.57 \mathrm{mg} / \mathrm{kg}$ (winter) and $1.59 \mathrm{mg} / \mathrm{kg}$ (spring). The order of the observed mean $\mathrm{Cr}$ contents in all forage samples were determined as autumn>summer>winter>spring. The mean $\mathrm{Cr}$ contents in forage samples showed inconsistent pattern of variation during various sampling seasons.

In the recent study all mean values of $\mathrm{Cr}$ observed were minimum than the values $(3 \mathrm{mg} / \mathrm{kg})$ observed by McDowell [55]. All mean values of $\mathrm{Cr}$ contents in forage were lesser than values reported by Ahmad et al. [56]. If higher levels of $\mathrm{Cr}$ are present in diet than tolerated level, $\mathrm{Cr}$ was accounted to be very toxic for livestock [57].

The forage plants may absorb metal deposits on the plant parts surfaces exposed to a polluted environment as well as toxic metals from soil under specific conditions. Moreover, for forage plants heavy metals present in fertilizers is the other source of metal pollution. Despite of all this, metals like $\mathrm{Cu}, \mathrm{Co}, \mathrm{Zn}, \mathrm{Mn}$ and $\mathrm{Cr}$ are essential for plant and animal growth in trace amounts [58]. In the metabolism of living organisms, $\mathrm{Cr}$ also plays crucial role like other metals $[58,59]$.

\subsubsection{Blood plasma}

The mean $\mathrm{Cr}$ contents in blood plasma during various sampling seasons are listed in Table 7 and Table 8. According to the analysis of variance, blood plasma $\mathrm{Cr}$ content non-significantly affected by sampling seasons in young and dry buffaloes but it was significantly $(p<0.01)$ affected by the sampling seasons in lactating buffaloes. The mean values of $\mathrm{Cr}$ in blood plasma of lactating buffaloes were $0.475 \mathrm{mg} / \mathrm{L}$ (summer), $0.557 \mathrm{mg} / \mathrm{L}$ (autumn), $0.658 \mathrm{mg} / \mathrm{L}$ (winter) and $0.694 \mathrm{mg} / \mathrm{L}$ (spring). Cr content in blood plasma of dry buffaloes were $0.568 \mathrm{mg} / \mathrm{L}$ (summer), $0.594 \mathrm{mg} / \mathrm{L}$ (autumn), $0.668 \mathrm{mg} / \mathrm{L}$ (winter) and $0.666 \mathrm{mg} / \mathrm{L}$ (spring). The average contents of $\mathrm{Cr}$ in blood plasma of young buffaloes were $0.492 \mathrm{mg} / \mathrm{L}$ (summer), $0.612 \mathrm{mg} / \mathrm{L}$ (autumn), $0.656 \mathrm{mg} / \mathrm{L}$ (winter) and $0.506 \mathrm{mg} / \mathrm{L}$ (spring). Higher $\mathrm{Cr}$ contents were observed in dry buffaloes in the spring $\mathrm{Cr}$ and lower mean $\mathrm{Cr}$ contents were noticed in lactating buffaloes in summer sampling season (Figure 3). The noticed order of Cr contents was summer<autumn<winter<spring in lactating buffaloes, spring<summer<autumn<winter in dry buffaloes and summer<spring<autumn<winter in young buffaloes [59]. In blood Cr concentration was higher than the average value $(0.34 \mathrm{mg} / \mathrm{L})$ studied by Christensen et al. [60], while its value was lower in calves than the critical value as mentioned earlier. $\mathrm{Cr}$ absorption in fasting animals is low with approximate range of 0.522 to $3 \%$ because of $\mathrm{Cr}$ supplementation [61]. In recent study lower values found are than the $\mathrm{Cr}$ contents as observed by Burr [62]. In these specific area, levels of $\mathrm{Cr}$ in blood samples indicated $\mathrm{Cr}$ deficiency. $\mathrm{Cr}$ is very important to improve human and animal health [2]. Mineral supplementation is necessary like supplementation of $\mathrm{Cr}$ to the ruminants at this investigated area.

\subsection{Copper contents of samples}

\subsubsection{Soil}

The mean $\mathrm{Cu}$ concentrations in soil during various sampling seasons are summarized in Table 9 and Table 10. No significant seasonal or sampling intervals effect was observed on the mean $\mathrm{Cu}$ contents in soil samples. The mean $\mathrm{Cu}$ values in different sampling seasons were ranged from 3.54 to $4.08 \mathrm{mg} / \mathrm{kg}$. Higher mean $\mathrm{Cu}$ contents were found in soil samples collected during winter sampling season and lower $\mathrm{Cu}$ concentrations were observed during spring sampling season (Figure 4). The mean values of $\mathrm{Cu}$ contents at various sampling seasons were $3.65 \mathrm{mg} / \mathrm{kg}$ (summer), $3.84 \mathrm{mg} / \mathrm{kg}$ (autumn), $4.08 \mathrm{mg} / \mathrm{kg}$ (winter) and $3.54 \mathrm{mg} / \mathrm{kg}$ (spring). The order of the observed mean Cu values in all the soil samples were determined as winter>autumn>summer>spring. The mean $\mathrm{Cu}$ contents in soil samples exhibited inconsistent pattern of variation at different sampling seasons. 
Table 9. Analysis of variance for copper concentrations in soil, forage and blood plasma influenced by different seasons

\begin{tabular}{|c|c|c|c|c|c|c|}
\hline \multirow{2}{*}{$\begin{array}{c}\text { Source of } \\
\text { variation }\end{array}$} & \multirow{2}{*}{$\begin{array}{c}\text { Degrees } \\
\text { of } \\
\text { freedom }\end{array}$} & Soil & \multirow{2}{*}{ Forage } & \multicolumn{4}{|c|}{ Mean squares } \\
\cline { 3 - 7 } & & & & $\begin{array}{c}\text { Lactating } \\
\text { buffaloes }\end{array}$ & Dry buffaloes & $\begin{array}{c}\text { Young } \\
\text { buffaloes }\end{array}$ \\
\hline $\begin{array}{c}\text { Sampling } \\
\text { season }\end{array}$ & 3 & $1.675 \mathrm{ws}$ & $0.713^{\mathrm{ws}}$ & $0.011 \mathrm{w}$ & $0.002^{\mathrm{ws}}$ & $0.002^{\mathrm{ws}}$ \\
\hline Error & 36 & 0.370 & 1.233 & 0.001 & 0.001 & 0.001 \\
\hline
\end{tabular}

Table 10. Descriptive analysis for copper concentrations in soil, forage and blood plasma influenced by different seasons

\begin{tabular}{|c|c|c|c|c|c|}
\hline \multirow{2}{*}{ Parameter } & \multirow{2}{*}{ Soil } & \multirow{2}{*}{ Forage } & \multicolumn{4}{|c|}{ Blood plasma } \\
\cline { 4 - 6 } & & & $\begin{array}{c}\text { Lactating } \\
\text { buffaloes }\end{array}$ & Dry buffaloes & $\begin{array}{c}\text { Young } \\
\text { buffaloes }\end{array}$ \\
\hline Mean & & & 0.218 & 0.206 & 0.235 \\
\hline Std. Error \pm & 3.783 & 6.916 & 0.006 & 0.006 & 0.005 \\
\hline Median & 0.093 & 0.131 & 0.222 & 0.194 & 0.236 \\
\hline Mode & 3.663 & 6.732 & 0.287 & 0.287 & $0.172^{\mathrm{a}}$ \\
\hline Std. Deviation & $3.292^{2}$ & 8.725 & 0.068 & 0.060 & 0.054 \\
\hline Minimum & 1.017 & 1.435 & 0.107 & 0.107 & 0.101 \\
\hline Maximum & 1.427 & 4.265 & 0.387 & 0.346 & 0.379 \\
\hline
\end{tabular}

a. Multiple modes exist. The smallest value is shown

\section{Soil}

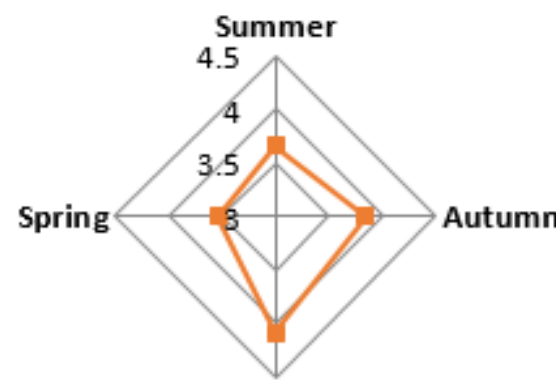

Winter

\section{Blood Plasma}

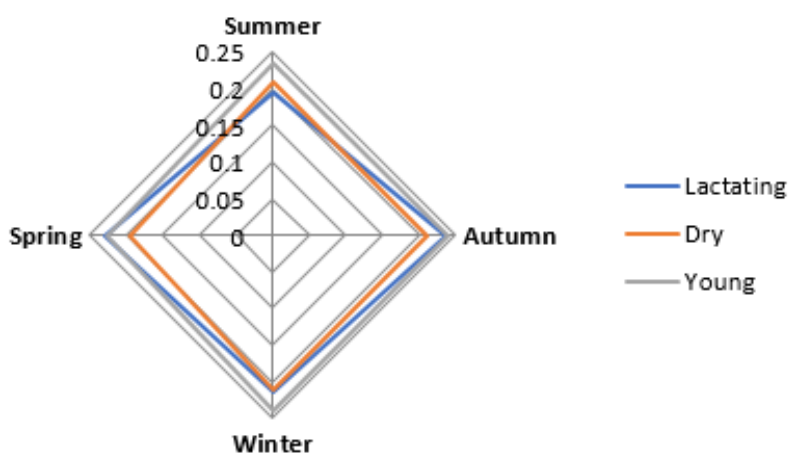

Forage

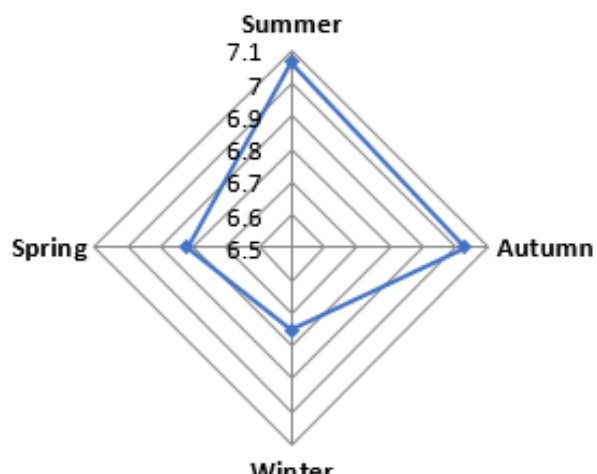

Winter

Figure 4. Fluctuations in copper values in soil, forage and blood plasma during different seasons 
All $\mathrm{Cu}$ concentrations in the present study were more than the findings $(1 \mathrm{mg} / \mathrm{kg})$ reported by McDowell et al. [63]. The present results were lower than observed by various researchers [64-68] and higher than reported by Khan et al. [69] and Yadav and Khirwar [70] reported comparable results.

\subsubsection{Forage}

The average values of $\mathrm{Cu}$ in forage during various sampling seasons are showed in Table 9 and Table 10. No significant seasonal or sampling intervals effect was noticed on the mean $\mathrm{Cu}$ contents in forage samples. The mean $\mathrm{Cu}$ values in different sampling seasons were ranged from 6.75 to 7.06 $\mathrm{mg} / \mathrm{kg}$. Higher mean $\mathrm{Cu}$ contents were found in forage samples collected during summer sampling season and lower $\mathrm{Cu}$ concentrations were observed during winter sampling season (Figure 4). The mean values of $\mathrm{Cu}$ contents at various sampling seasons were $7.06 \mathrm{mg} / \mathrm{kg}$ (summer), $7.02 \mathrm{mg} / \mathrm{kg}$ (autumn), $6.75 \mathrm{mg} / \mathrm{kg}$ (winter) and $6.81 \mathrm{mg} / \mathrm{kg}$ (spring). The order of the observed $\mathrm{Cu}$ mean values in all forage samples were determined as summer>autumn>spring>winter. The mean $\mathrm{Cu}$ contents in forage samples exhibited variable pattern of findings at different sampling seasons.

In this research all mean values of $\mathrm{Cu}$ investigated were lesser $(10 \mathrm{mg} / \mathrm{kg})$ as described by McDowell et al. [63]. These $\mathrm{Cr}$ values were different from the values calculated in Indonesia by Prabowo et al. [70] and the minimum than the values determined by [71,72] in Guatemala. The values determined by $[27,28,73]$ in Pakistan were higher than the $\mathrm{Cu}$ values investigated in recent observation. In forages the concentration of $\mathrm{Mo}$ and $\mathrm{S}$ has opposing effect on $\mathrm{Cu}$ concentration [74]. In forage the $\mathrm{Cu}^{2+}$ low concentration is due to its interaction with other metals. $\mathrm{Cu}$ contents were reduced as the Fe level increases which also so the antagonistic affect upon each other $[75,76]$.

\subsubsection{Blood plasma}

The average $\mathrm{Cu}$ values in blood plasma during various sampling seasons are showed in Table 9 and Table 10. The mean $\mathrm{Cu}$ contents in blood plasma non-significantly $(p>0.05)$ affected by sampling seasons in all the three categories of buffaloes (lactating, dry and young). The mean values of $\mathrm{Cu}$ in blood plasma of lactating buffaloes were $0.193 \mathrm{mg} / \mathrm{L}$ (summer), $0.236 \mathrm{mg} / \mathrm{L}$ (autumn), $0.213 \mathrm{mg} / \mathrm{L}$ (winter) and $0.230 \mathrm{mg} / \mathrm{L}$ (spring). The $\mathrm{Cu}$ contents in blood plasma of dry buffaloes were $0.210 \mathrm{mg} / \mathrm{L}$ (summer), $0.209 \mathrm{mg} / \mathrm{L}$ (autumn), $0.211 \mathrm{mg} / \mathrm{L}$ (winter) and $0.193 \mathrm{mg} / \mathrm{L}$ (spring). The average contents of $\mathrm{Cu}$ in blood plasma of young buffaloes were $0.233 \mathrm{mg} / \mathrm{L}$ (summer), $0.240 \mathrm{mg} / \mathrm{L}$ (autumn), 0.239 $\mathrm{mg} / \mathrm{L}$ (winter) and $0.224 \mathrm{mg} / \mathrm{L}$ (spring). Higher mean $\mathrm{Cu}$ contents were observed in young buffaloes during autumn season and lower mean $\mathrm{Cu}$ contents were noticed in lactating buffaloes in summer sampling season (Figure 4). The detected order of $\mathrm{Cu}$ mean contents was autumn $>$ spring> winter $>$ summer in lactating buffaloes, winter $>$ summer $>$ autumn $>$ spring in dry buffaloes and autumn $>$ winter>summer>spring $>$ in young buffaloes.

Copper contents in the present study were less $(0.65 \mathrm{mg} / \mathrm{L})$ as reported by McDowell [77]. $\mathrm{Cu}$ content found in the present investigation was lower as observed by Bhardwaj et al. [78] and in comparison with values noticed by Khan et al. [17]. In general, the deficiency of $\mathrm{Cu}$ affects the reproduction and physiological functions. In haemoglobin formation and $\mathrm{Fe}$ transportation, $\mathrm{Cu}$ plays crucial role. The activity of estrus in ruminants is disturbed by the deficiency of $\mathrm{Cu}$ [79]. Therefore, $\mathrm{Cu}$ supplementation of the animals is necessary.

Copper content in growing tissues in which liver is included as part of the carcass, is about 1.15 $\mathrm{mg} / \mathrm{kg}$ based primarily on studies of buffaloes and sheep. Excess of absorbed $\mathrm{Cu}$ is stored in liver, where concentrations of $\mathrm{Cu}$ can be much more depending upon diet. The dietary $\mathrm{Cu}$ required supplying the $\mathrm{Cu}$ needed for lactation growth and maintenance will change with animal age and various factors. Reproductive inefficiency osteoporosis, cardiac failure, poor growth, fragile bones and anemia (hypochromic macrocytic) considered by depressed estrus also noticed in $\mathrm{Cu}$ deficiency [80]. 


\subsection{Bioconcentration factor}

Bioconcentration factor was evaluated as said by Sajjad and Khan [81] who stated it as metal relative tendency to be accumulated by a plant species. In general, BCF indicates bioavailability of metal at a position on a plant species. Plants uptake metals and it is affected by different factors such as metal in soils, $p \mathrm{H}$ of soil, organic matter content, cation exchange capacity, types, varieties and age of plants. Generally, it is accepted that the metal in soil is dominant factor. It is due to the reason that different BCF have been reported for the same species of vegetables, their different parts such as roots and leafy parts by different authors. In this study BCF calculated depends upon plant total metal contents irrespective of its different parts [82].

$\mathrm{BCF}$ of Cd from soil-forage-blood plasma is summarized in Table 11. The determined BCF for Cd content from soil to forage during different sampling seasons were 0.721 (summer), 0.451 (autumn), 0.654 (winter) and 0.616 (spring). The observed transfer factor for $\mathrm{Cd}$ content from forage to blood plasma in lactating buffaloes were 1.272 (summer), 2.602 (autumn), 2.357 (winter) and 1.944 (spring); in dry buffaloes were 1.474 (summer), 2.796 (autumn), 1.914 (winter) and 2.090 (spring); in young buffaloes were 1.991 (summer), 3.248 (autumn), 2.278 (winter) and 2.337 (spring). The highest transfer factor for Cd content was found in forage-young buffalo at autumn sampling season and the lowest was in soil-forage during autumn sampling season. Cadmium uptake by vegetables is a function of forms of $\mathrm{Cd}$ in soils. The presence of soluble compounds or ions temperature, soil organic matter, total $\mathrm{Cd}$ content, redox potential and $\mathrm{pH}$, are the properties of soil influencing $\mathrm{Cd}$ uptake in vegetables [83]. Cd is the most dangerous metals because of its high mobility and its small concentration at where it effect on vegetables begin to appear [84]. The determined BCF for $\mathrm{Cr}$ from soil to forage during different sampling season was 53.971 (summer), 57.804 (autumn), 33.134 (winter) and 51.674 (spring). The noticed BCF for $\mathrm{Cr}$ content from forage to blood plasma in lactating buffaloes were 0.011 (summer), 0.007 (autumn), 0.019 (winter) and 0.017 (spring); in dry buffaloes were 0.013 (summer), 0.008 (autumn), 0.020 (winter) and 0.016 (spring); in young buffaloes were 0.012 (summer), 0.008 (autumn), 0.019 (winter) and 0.012 (spring). The minimum transfer factor for Cr content was found in forage-lactating buffalo at autumn sampling season and the maximum was in soil-forage during autumn sampling season. The Cr had the highest BCF value and this could be attributed to the low retention rate of the metal in soil and therefore it is more mobile in the soil.

Table 11. Bioconcentration factor of cadmium, chromium and copper from soil- forage-blood plasma

\begin{tabular}{|c|c|c|c|c|c|}
\hline \multirow{3}{*}{ Metal } & \multirow{3}{*}{ Samplings season } & \multicolumn{4}{|c|}{ Bioconcentration factor } \\
\hline & & \multirow[b]{2}{*}{ Soil to forage } & \multicolumn{3}{|c|}{ Forage to blood plasma } \\
\hline & & & $\begin{array}{l}\text { Lactating } \\
\text { buffaloes }\end{array}$ & $\begin{array}{c}\text { Dry } \\
\text { buffaloes }\end{array}$ & $\begin{array}{c}\text { Young } \\
\text { buffaloes }\end{array}$ \\
\hline \multirow{4}{*}{ Cd } & Summer & 0.721 & 1.272 & 1.474 & 1.991 \\
\hline & Autumn & 0.451 & 2.602 & 2.796 & 3.248 \\
\hline & Winter & 0.654 & 2.357 & 1.914 & 2.278 \\
\hline & Spring & 0.616 & 1.944 & 2.090 & 2.337 \\
\hline \multirow{4}{*}{$\mathbf{C r}$} & Summer & 53.971 & 0.011 & 0.013 & 0.012 \\
\hline & Autumn & 57.804 & 0.007 & 0.008 & 0.008 \\
\hline & Winter & 33.134 & 0.019 & 0.020 & 0.019 \\
\hline & Spring & 51.674 & 0.017 & 0.016 & 0.012 \\
\hline \multirow{4}{*}{$\mathrm{Cu}$} & Summer & 8.256 & 0.014 & 0.015 & 0.017 \\
\hline & Autumn & 7.615 & 0.018 & 0.016 & 0.019 \\
\hline & Winter & 6.887 & 0.019 & 0.019 & 0.022 \\
\hline & Spring & 8.552 & 0.018 & 0.015 & 0.017 \\
\hline
\end{tabular}

The detected $\mathrm{BCF}$ for $\mathrm{Cu}$ concentrations from soil to forage during different sampling seasons were 8.256 (summer), 7.615 (autumn), 6.887 (winter) and 8.552 (spring). The determined transfer factor for $\mathrm{Cu}$ concentration from forage to blood plasma in lactating buffaloes were 0.014 (summer), 0.018 (autumn), 0.019 (winter) and 0.018 (spring); in dry buffaloes were 0.015 (summer), 0.016 (autumn), 
0.019 (winter) and 0.015 (spring); were 0.017 (summer), 0.019 (autumn), 0.022 (winter) and 0.017 (spring). The lowest transfer factor for $\mathrm{Cu}$ concentration was found in forage-lactating buffalo at summer sampling season and the highest was in soil-forage during spring sampling season. Hofmann et al. [85] pointed out that the vegetables grown around industrial spots cause health hazard to poor communities, especially to the children and also observed higher $\mathrm{Cu}$ uptake in vegetables. The concentrations of $\mathrm{Cu}$ in vegetables usually do not rise to the levels where toxicity occurs. In the roots excess of $\mathrm{Cu}$ accumulates even under conditions of $\mathrm{Cu}$ toxicity and very minute quantity is carried to the aerial parts of vegetables [21].

\subsection{Correlation}

By using Pearson correlation coefficient method relationship between metal concentrations was established and presented in Table12. The investigated Cd correlation of soil with forage was negative and no significant $(r=-0.262)$ while it was positive and no significant between forage-blood plasma $(r=0.006)$ and blood plasma-soil $(r=0.994)$. The observed $\mathrm{Cr}$ correlation of soil with forage was negative and no significant $(r=-0.211)$ while it was positive and no significant between forage-blood plasma $(r=0.405)$ and blood plasma-soil $(r=0.595)$. The noticed $\mathrm{Cu}$ correlation of soil with forage was negative and no significant $(r=-0.349)$ and forage-blood plasma $(r=-0.013)$, while it was positive and no significant between blood plasma-soil $(r=0.987)$.

Table 12. Correlation of various minerals between Soil-Forage, Forage-Blood plasma and Blood Plasma-Soil

\begin{tabular}{|c|c|c|c|}
\hline \multirow{2}{*}{ Metal } & Soil-Forage & Forage-Blood plasma & Blood plasma-Soil \\
\hline $\mathbf{C d}$ & -0.262 & 0.006 & 0.994 \\
\hline $\mathbf{C r}$ & -0.211 & 0.405 & 0.595 \\
\hline $\mathbf{C u}$ & -0.349 & -0.013 & 0.987 \\
\hline
\end{tabular}

These findings corroborate with some earlier studies which also exhibited weak or no correlations among different parameters $[27,71]$.

\section{Conclusions}

It was concluded that the values of physico-chemical properties of soil and water samples were found within the safe limit recommended by world health organization. The values of heavy metals such as $\mathrm{Cd}$ values in the soil samples, and $\mathrm{Cr}$, values in blood plasma samples were higher than their permissible limits. The values of correlation between soil-forage for $\mathrm{Cd}, \mathrm{Cu}$ and $\mathrm{Cr}$ were negative and non-significant and from from forage to bloodplasm were positive and significant. According to the results of the present research, it can be said that there is a need for a continuous monitoring of contamination level of heavy metals in the study area and other areas in Pakistan since these metals can increase to toxic levels.

\section{Ethics}

All the study protocols were approved by Institutional Animal Ethics Committee, University of Sargodha (ApprovalNo.25-A18 IEC UOS). All the experiments performed complied with the rules of National Research Council (1996) and all methods were performed in accordance with relevant guidelines and regulations.

Acknowledgments. The author would like to thank all the members (Co-authors) for all of their help, advice, and information provided for this study. This manuscript was a minor part of the Ph.D. thesis by Mian Jahan Zaib Rasheed. 


\section{References}

1.AKHTAR, M.S., ASIMFAROOQ, A., AKBARLODHI, L., MUHAMMAD, S., MAZHARAYAZ, M., LASHARI, M.H., HUSSAIN, M., Studies on serum macro and micro minerals status in repeat breeder and normal cyclic Nili-Ravi buffaloes and their treatment strategies, African. J. Biotechn., 13, 2014.

2.SALEH, A.A., EBEID, T.A., EID, Y.Z., The effect of dietary linseed oil and organic selenium on growth performance and muscle fatty acids in growing rabbits, Pak. Vet. J., 33, 2013, 450-454

3.ENGLE, T.E., Trace minerals, vitamins and preventative nutrition, Feed stuffs., 73, 2001, 11-18.

4.MCDOWELL, L.R., VALLE, G., Macro minerals in forages. In: D.I. GIVENS, E. OWEN, R.F.E. OXFORD AND H.M. OMED (Eds.) Forage Evaluation in Ruminant Nutrition. CAB International, Wallingford, UK, 2000, p. 373.

5.ARTHINGTON, J.D. Essential trace minerals for grazing cattle in Florida: University of Florida Cooperative Extension Service, Institute of Food and Agriculture Sciences, EDIS, 2000.

6.PASTRANA, R., MCDOWELL, L.R., CONRAD, J.H., WILKINSON, N.S. Macromineral status of sheep in the Paramo region of Colombia. Small. Rumin. Res., 5, 1991, 9-21

7.VUKADINOVIC, V., BERTIC, B., Agrochemistry and Plant Nutrition. University J.J.Strossmayer in Osijek, Faculty of Agriculture (in Croatian) Osijek, Croatia, 1988.

8.DE-VOS, B., LETTENS, S., MUYS, B., DECKERS, J.A., Walkley-Black analysis of forest soil organic carbon: recovery, limitations and uncertainty. Soil Use Manag., 23, 2007, 221-229

9.STEEL, P., KÖNIG, C.J., Integrating theories of motivation. Acad. Manag. Rev., 31, 2006, 889-913. 10.KUMAR, N., SINHA, D.K., Drinking water quality management through correlation studies among various physicochemical parameters: A case study. Int. J. Environ. Sci., 1, 2010, 0976 - 4402 11.SMICIKLAS-WRIGHT, H., MITCHELL, D., MICKLE, S., COOK, A., GOLDMAN, J., Foods commonly eaten in the United States: quantities consumed per eating occasion and in a day. US Department of Agriculture NFS report 2002, p. 252

12.PATTANAYAK, S., NAYAK, S.S., PANDA, D.P., DINDA, S.C., SLENDE, U., JADAV, A., Hepatoprotective activity of crude flavonoids extract of Cajanus scarabaeoides (L.) in paracetamol intoxicated albino rats. Asian J. Pharm. Boi. Res., 1, 2011, $22-27$.

13.YADAV, S., KHIRWAR, S.S., Soil plant animal relationship of zinc in milch buffaloe of Zind district in Haryana, Indian J. Anim. Sci., 70, 2000, 965-967

14.ASHRAF, M.Y., KHAN, A., ASHRAF, M., Sodium transfer from soil, forage, feed and water to lactating and non-lactating buffalos under arid environment, Buffalo Bull., 26, 2007, 29-35

15.MCDOWELL, L.R., Nutrition of Grazing Ruminants in Warm Climates. Academic Press New York, 1985, p. 443.

16.LOGAN, T.J., MILLER, R.H., Background Levels of Heavy Metals in Ohio Farm Soils. Research Circular 275. The Ohio State University Agricultural Research and Development, Wooster, Ohio, 1983, p. 1.

17.KHAN, Z.I., AHMAD, K., AKRAM, N.A., MUSTAFA, I., IBRAHIM, M., FARDOUS, A., GONDAL, S., HUSSAIN, A., ET AL., Heavy Metals Concentration in Soil-Plant-Animal Continuum under Semi-Arid Conditions of Punjab, Pakistan. Pak. J. Zool., 47, 2015, 377-382.

18.PIERCE, M.L., MOORE, C.B., Absorption of arsenite and arsenate on amorphous iron hydroxide, Water Res., 16, 1982, 1247.

19.KHAN, Z.I., ASHRAF, M., AHMAD, K., VALEEM, E.E., Periodic evaluation of potassium transfer from soil and forage to small ruminants on an experimental station in southern Punjab, Pakistan, Pak. J. Bot., 42, 2010, 1353-1360

20.RASHID, A., MEMON, A.R., BASHIR, E., MIAN, H.R. Soil and Plant Analysis Laboratory Analysis. ICARDA, Allepo, Syria and NARC, Islamabad, Pakistan, 2001.

21.SINGH, A.Y., Equilibria availably and pollution hazard of sludge born nickel and cobalt in soil and plant. Ph.D. thesis. Rajendera Prasad Agricultural University PUSGI, Bihar, India, 2005. 
22.KLOKE, A., Richtwerete ' 80 orientierungsdaten fur tolerierbare Gesamtgehalte einiger Elemente in Kulturboden. Mih Vdlufa 1, 1980, 9-11

23.CICEK, N., ZHANG, Q., ZUBRISKI, S., EVANS, C., Fate of selected heavy metals during gasification of municipal biosolids. J. Resid. Sci. Technol., 1, 2004, 223-230

25.AKSOY, A., HALE WH, DIXON JM (1999) Capsella bursa-pastoris (L.) Medic. as a biomonitor of heavy metals. Sci Total environ 226:177-186

25.GOWDA, N.K.S., MALATHI, V.S., JASH, S., ROY, K.S., Status of pollutants and trace elements in water, soil, vegetation and dairy animals in industrial area of Bangalore. Indian J. Dairy Sci., 56, 2003, 86-90

26.KABATA-PENDIAS, A., PENDIAS, H., Trace elements in Soil and Plants. CRC Press Inc., Boca Raton, 1992.

27.MTIMUNI, J.P., Identification of mineral deficiencies in soil, plant and animal tissues as constraints to cattle production in Malawi. Ph.D. Dissertation. Univ. Florida, Gainesville, 1982.

28.KHAN, Z.I., HUSSAIN, A., ASHRAF, M., MCDOWEL, L.R., Mineral Status of Soils and forages in southwestern Punjab-Pakistan: Micro-minerals. Asian-Aust. J. Anim. Sci., 19, 2006,1139-1147

29.KHAN, Z.I., ASHRAF, M., AHMAD, K., MUSTAFA, I., DANISH, M., Evaluation of micro mineral composition of different grasses in relation to live stock requirements. Pak. J. Bot., 39, 2007, 719-728

30.*** WHO, Study Group. Recommended health-based limits in occupational exposure to heavy metals.Friberg L Vahter M. Assessment of exposure to lead and cadmium through biological monitoring: results of a UNEP/WHO global study 1983. Environ. Res., 30, 1983, 95-128

31.MERIAN, E., Metals and their Compounds in the Environment. VCH, Weinheim-New York-BaselCambridge, 1991.

32.O’NEILL, P., Heavy Metals in Soils. Blackie Academic and Professional, London, 1995.

33.MCDOWELL, L.R., Minerals in Animal and Human Nutrition. Academic Press, New York, 1992. 34.***NRC, Minerals In: National Research Council, editors. Nutrient requirements of dairy cattle. Washington: National Academy Press, 2001, p. 105-61.

35.KUESTER, R.K., WAALKES, M.P., GOERING, P.L., FISHER, B.L., MCCUSKEY, R.S., SIPES, I.G., Differencial hepatotoxicity induced by cadmium in Fisher 344 and Sprague-Dawley rats. Toxicol. Sci., 65, 2002, 151-159.

36.STANEVIČIENÉ， I., SADAUSKIENĖ， I., LESAUUSKAITÉ, V., IVANOVIENÉ, L., KAŠAUSKASAND, A., IVANOV, L., Subacute effects of cadmium and zinc ions on protein synthesis and cell death in mouse liver. Medicina (Kaunas) 44, 2008, 131-136.

37.SHIMODA, R., NAGAMINE, T., TAKAGI, H., MORI, M., WAALKES, M.P., Introduction apoptosis in cells by cadmium: quantitative negative correlation between basal or induced metallothionein concentration and apoptotic rate. Toxicol. Sci., 64, 2001, 208-215.

38.WAISBERG, M., JOSEPH, P., HALE, B., BEYERSMANN, D., Molecular and cellular mechanisms of cadmium carcinogenesis. Toxicol., 192, 2003, 95- 117.

39.SMALINSKIENĖ, A., GAILEVIČIŪTĖ, R., LESAUSKAITE, V., SAUDAUSKIENÉ, I., ABDRAKHMANOV, O., IVANOV, L., Effects of cadmium and zinc íons on mitotic activity and protein synthesis in mouse liver, Medicina (Kaunas), 41, 2005, 506-511.

409.NEWAIRY, A.A.., EL-SHARAKY, A.S, BALDRELDEEN,. M.M. ET AL., The hepatoprotective effects of selenium against cadmium toxicity in rats. Toxicol., 242, 2007, 23-30.

41.KIM, S.C., CHO, M.K., KIM, S.G., Cadmium induced non-apoptotic cell death mediated by oxidative stress under condition of sulfhydryl deficiency. Toxicol. Lett., 144, 2003, 325-336.

42.IVANOV, L., LESAUSKAITE, V., IVANOVIENE, L., SADAUSKIENE, I., GAILEVICIŪTE, R., ET AL., Effects of cadmium ions on the initial stage of translocation and the cell death in mouse liver. Medicina (Kaunas, ) 41, 2005, 47-53.

43.HABEEBU, S.S., LIU, .J, KLAASSEN, C.D., Cadmium-induced apopitosis in mouse liver. Toxicol. Appl. Pharmacol., 149, 1998, 203-209. 
44.ANDERSON, A.J., MEYER, D.R., MAYER, F.K., Heavy metal toxicities levels of nickel, cobalt and chromium in the soil and plants associated with visual symptoms and variation in growth of an oat crop. Austral. J. Agri. Res., 24, 1972, 557-571.

45.MCBRIDE, M.B., Environmental chemistry of soils. Oxford University Press, New York, 1994. 46.BARON, D., STANLEY, J.T., PALMER, C.D., Identification of two Fe-chromate minerals in chromium (IV) - contaminated Soil. Environ. Sci. Technol., 30, 1996, 964-968

47.NRIAGU, J.O., PACYNA, J.M., Quantitative assessment of worldwide contamination of air, water and soil by trace metals. Nature, 333, 1988, 134-139.

48.BARCELOUX, D.G., Chromium. J. Toxicol. Clin. Toxicol .,37, 1999, 173-194/

49.KIMBROUGH, D.E., COHEN, Y., WINER, A.M., CREELAM, L., MABUNI, C.A., critical assessment of chromium in the environment. Crit. Rev. Environ. Sci. Technol., 29, 1999, 1-46. 50.UNDERWOOD, E.J., SUTTLE, N.F., The Mineral Nutrition of Livestock. Midlothian, UK, 1999. 51.WU, Y.G., YOUNING, X.U., JIANGHUA, Z., SIHAI, H.U., Evaluation of ecological risk and primary empirical research on heavy metals in polluted soil over Xiaoqinling gold mining region, Shaanxi, China, Trans. Nonferrous Me.t Soc. China, 20, 2010, 688-694.

52.GHANEM. M., SHALABY, A.H., SHARAWY, S., SALEH, N., Factors Leading to Endometritis in Dairy Cows in Egypt with Special Reference to Reproductive Performance. J. Reprod. Devel., 48, 2002, 371-375.

53.RUI, L.F., FEN, K.L., QING, G.X, WEI, H., WANG, Y.F., LONG, H.W., Traffic-Related heavy metal accumulation in soils and plants in Norwest China. Soil Sedim. Contam., 16, 2007, 473-484

54.KELLY, J., THORNTON, I., SIMPSON, P.R., Urban geochemistry: a study of influence of anthropogenic activity on heavy metal content of soils in traditionally industrial and non-industrial areas of Britain. Appl. Geochem., 11, 1996, 363-370.

55.MCDOWELL, L.R., Nutrition of Grazing Ruminants in Warm Climates. Academic Press, New York, 1985.

56.AHMAD, K., KHAN, Z.I., ASHRAF, M., VALEEM, E.E., SHAH, Z.A., MCDOWELL, L.R., Determination of forage concentration of lead, nickel and chromium in relation to the requirement of grazing ruminants in the salt range. Pak. J. Bot., 41, 2009, 61-65.

57.ANONYMOUS, Analytical Methods for Atomic-Absorption Spectrophotometry. Perkin-Elmer, Norwalk, Connecticut, 1980.

58.TOKALIOGLU, S., KARTA, L.S., GUNIS, A.A., Determination of heavy metalin soil extracts and plant tissues at around of zinc smelter. Int. J. Environ. Analyt. Chem., 80, 2000, 210-217.

59.MCDOWELL, L.R., Minerals in animals and human nutrition. Elsevier Science BV. Amsterdam, The Netherlands, 2003.

60.CHRISTENSEN, J.M., HOLST, E., BONDE, J.P., KNUDSEN, L., Determination of chromium in blood and serum - evaluation of quality control procedures and estimation of reference values in danish subjects. Sci. Total Environ., 132, 1993, 11-25

61.LI, Y.C., STOECKER, B.J., Chromium and yogurt effects on hepatic lipid and plasma glucose and insulin of obese mice. Biol. Trace Element Res., 9, 1986, 233-242.

62.BURR, R.G., Plasma-Zinc Levels. Lancet I, 1974, 879.

63.MCDOWELL, L.R., CONRAD, J.H., ELLIS, G.L., LOOSLI, L.K., Minerals for grazing ruminants intropical regions. Gainesville, University of Florida, 1983.

64.GUPTA, V.K., GUPTA, S.P., RAMA, K., Micro nutrient status of Haryana soils. Haryana Farmings, 25, 1995, 12-14.

65.KHAN, Z.I., AHMAD, K., DANISH, M., MIRZA, M.A., MIRZAEI, F., Selenium profile in blood plasma of grazing sheep: A case study in specific ranch in Punjab, Pakistan. Agri. Sci., 3, 2012, 470.

66.KHAN, Z.I., AHMAD, K., MUKHTAR, M.K., MIRZAEI, F., HUSSAIN, G., Assessment of pasture and plasma minerals of cows: A case study in Pakistan. Agri. Sci., 4, 2013, 57 
67.KHAN, Z.I., AHMAD, K., AKRAM, N.A., MUSTAFA, I., IBRAHIM, M., FARDOUS, A., GONDAL, S., ET AL., Heavy Metals Concentration in Soil-Plant-Animal Continuum under SemiArid Conditions of Punjab, Pakistan, Pak. J. Zool., 47, 2015, 377-382

68.KAPADIY, F., SIDDIQUEE, G., Blood plasma trace elements in repeat breeding Mehsana buffaloes, The Indian J. Anim. Reprod, 33, 2015.

69.KHAN, Z.I., AHMED, K.., ASHRAF, M., VALEEM, E.E., JAVED, I., A Comparative Study on Mineral Status of Blood Plasma of Small Ruminants and Pastures in Punjab, Pakistan, Pak. J. Bot., 41, 2008, 67-72.

70.PRABOWO, A., MCDOWELL, L.R., WILKINSON, N.S., WILCOX, C.J., CORNAD, J.H., Mineral Status of Grazing cattle in South Sulawesi, Indonesia; 1 Macrominerals. Am. J. Anim. Sci., 4, 1990, 111-120.

71.TEJADA, R., MCDOWELL, L.R., MARTIN, F.G., CONRAD, J.H., Mineral element analyses of various tropical forages in Guatemala and their relationship to soil concentrations, Nutr. Rep. Int., 32, 1985, 313-323.

72.TEJADA, R., MCDOWELL, L.R., MARTIN, F.G., CONRAD, J.H., Evaluations of cattle trace mineral status in specific region of Guetemala, Trop Agric (Trinidad), 6, 1987, 55-60

73.MCDOWELL, L.R., KIATOKO, M., BERTRAND, J.E., CHAPMAN, H.L ET AL., Evaluating the nutrition status of beef cattle from four soil order regions of Florida: II. Trace min. J. Anim. Sci., 55, $82,38-47$.

74.DAVENDRA, C., Trees and shrubs and sustainable sources. Proceedings of the world conference on animal production. Endmonton, 10, 1993, 119-136.

75.PHILLIPO M, HUMPHRIES WR, GARTHWAITE PH., The effect of dietary molubdenum and iron on copper status and growth in cattle, J. Agri. Sci., 109, 1987, 315.

76.DAVIS, G.K., MERTZ, W., Copper. In: Trace Elements in Human and Animal Nutrition (Mertz, W., ed.), 5th $\tilde{A} @$ d., Academic Press, San Diego, CA, 1987, p. 301-364.

77.MCDOWELL, L.R., Minerals for Grazing Ruminants in Tropical Regions. Extension Bulletin, Anim. Sci. Dept. Centre for Trop. Agric., Univ. Florida, p. 81

78.BHARDWAJ, R.L., ROY, K.S., SRIVASTAVA, A.K., Normal levels of some macro-and microminerals and hormones in the ovarian tissues of pregnant and cyclic buffaloes (bubalus bubalis), Indian J. Anim. Sci., 68, 1998, 448-449.

79.SUTTLE, N.F., MCLAUCHLIN, M., Predicting the effects of dietary molybdenum and sulphur on the availability of copper to ruminants, The Proc. Nutr. Soci., 35, 1976, 22A-23A.

80.UNDERWOOD, E.J., The Mineral Nutrition of Livestock. Common wealth Agricultural Bureaux, Slough, England, 1981.

81. SAJJAD, M., KHAN, F.A., Genetic Diversity among Sugarcane Cultivars in Pakistan, AmericanEurasian J. Agri. Environ. Sci., 6, 2009, 730-736.

82.ADRIANO, D.C. Trace Elements in the Terrestrial Environment. Springer, New York, 1986.

83.RUPA, T.R., RAO, C.S., RAO, A.S., SINGH, M., Effects of farmyard manure and phosphorus on zinc transformations and phyto availability in two alfisols of India. Biores. Technol., 87, 2003, 279288.

84.BENAVIDES, M.P., GAlleGO, S.M., TOMARO, M.L., Cadmium toxicity in plants. Braz. $J$. Plant. Physiol., 17, 2005, 21-34.

85.HOFMANN, M., GUSCHEL, M., BERND, A., BEREITER-HAHN, J., KAUFMANN, R., TANDI, C., KIPPENBERGER, S., Lowering of tumor interstitial fluid pressure reduces tumor cell proliferation in a xenograft tumor model, Neoplasia, 8, 2006, 89-9.

Manuscript received: 10.06 .2020 